\title{
Pd-catalysed amidation of 2,6-dihalopurine nucleosides. Replacement of iodine at $0{ }^{\circ} \mathrm{C}$
}

\author{
Lluís Bosch, Ionela Cialîcu, Joaquim Caner, Xavier Ariza, Anna M. Costa, Montserrat Terrazas, \\ Jaume Vilarrasa* \\ Departament de Química Orgànica, Facultat de Química, Universitat de Barcelona, Diagonal 647, 08028 Barcelona, Catalonia, Spain
}

\section{A R T I C L E I N F O}

\section{Article history:}

Received 27 November 2011

Revised 22 December 2011

Accepted 4 January 2012

Available online $\mathrm{xxxx}$

\section{Keywords:}

$\mathrm{C}-\mathrm{N}$ bond formation

Pd insertions at $0{ }^{\circ} \mathrm{C}$

2,6-Diaminopurine derivatives

\begin{abstract}
A B S T R A C T
Pd-catalysed reactions of 2-Cl, 2- $\mathrm{Br}$ and 2-I derivatives of a 6-chloropurine nucleoside with benzamide have been compared, using $\mathrm{Pd}_{2} \mathrm{dba}_{3}$, Xantphos and $\mathrm{Cs}_{2} \mathrm{CO}_{3}$ in toluene, between 20 and $80{ }^{\circ} \mathrm{C}$. The reactivity order was $2-\mathrm{I}>2-\mathrm{Br}>6-\mathrm{Cl} \gg 2-\mathrm{Cl}$. The 2 -I substituent could be replaced even at $0{ }^{\circ} \mathrm{C}$, under conditions disclosed here for the first time. On the other hand, the replacement of the chlorine atom at position 2 (2$\mathrm{Cl})$ required $110^{\circ} \mathrm{C}$.
\end{abstract}

(c) 2012 Elsevier Ltd. All rights reserved.
In spite of the remarkable advances in transition metal-catalysed cross-coupling reactions for the formation of carbon-carbon and carbon-heteroatom bonds in heterocycles and nucleosides, ${ }^{1}$ there continues to be an increasing demand of new improvements. Control of the cross couplings of dihalo or trihalo derivatives of purines and their nucleosides with nucleophiles has interest because of the biological or medicinal significance of the resulting products. In particular, selective substitutions can provide alternative routes to the analogues and surrogates of purine-derived known anticancer agents ${ }^{2}$ and, in general, to adenosine receptor agonists or antagonists. ${ }^{3}$

In the past years we have been interested in ring modifications of nucleosides, aimed at preparing endo and exo ${ }^{15} \mathrm{~N}$-labeled samples. Ring nitrogen labels were introduced by means of new ringopening-ring-closing reactions, while exocyclic labels came from Buchwald-Hartwig amidation reactions of chloropurine nucleosides with $\left[{ }^{15} \mathrm{~N}\right]$ benzamide. ${ }^{4}$ In this way, we achieved the synthesis of $\left[{ }^{15} \mathrm{~N}_{2}\right]$ adenosines and $\left[{ }^{15} \mathrm{~N}_{2}\right]-2^{\prime}$-deoxyadenosines ${ }^{4 \mathrm{~d}}$ and of $\left[{ }^{15} \mathrm{~N}_{2}\right]$ guanosines. ${ }^{4 \mathrm{e}}$

In this context, we planned to compare the reactivity of dihalo derivatives of 9-(2',3',5'-tri-O-acetylribofuranosyl)purines 1-3 among them and against different kinds of amides. Differences were expected, ${ }^{1}$ but we found out suitable conditions for the selective replacement of one halogen or the other, including those for the replacement of I at $0{ }^{\circ} \mathrm{C}$, which we report here for the first time.

\footnotetext{
* Corresponding author. Tel.: +34 93 4021258; fax: +34 933397878.

E-mail address: jvilarrasa@ub.edu (J. Vilarrasa).
}

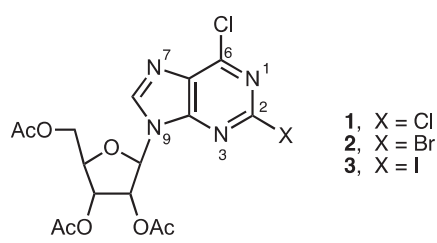

Purine nucleosides, owing to their sensitivity to Lewis and Brönsted acids, which may give rise to the cleavage of the anomeric bonds and removal of the protecting groups (PGs), and to baseswith the removal of some PGs as well-are ideal substrates for testing the performance of a catalytic system; mild reaction conditions and short reaction times are a must, otherwise decomposition products predominate. In sharp contrast to what happens in many cross-coupling reactions, the substrates are often ${ }^{4 e}$ much more expensive than the Pd and P reagents. In the present work we have used nucleosides with Ac groups as PGs, as they were the most convenient during the synthesis of the starting materials. As it is also known, unlike $S_{N} A r-l i k e$ reactions, where the order of substitution of aryl halides by a nucleophilic nitrogen is usually $\mathrm{F}>\mathrm{Cl}>\mathrm{Br}>\mathrm{I},{ }^{5}$ in $\mathrm{Pd}$-catalysed reactions the opposite order is observed, $\mathrm{I}>\mathrm{Br} \gg \mathrm{Cl} \gg>\mathrm{F}^{1}$, since the insertion of $\mathrm{Pd}^{0}$ into the $\mathrm{C}-\mathrm{X}$ bond is generally the rate-determining step. Moreover, in 2,6-dichloro derivative 1, position 6 is the most reactive (both in Pd-catalysed and $\mathrm{S}_{\mathrm{N}} \mathrm{Ar} / \mathrm{S}_{\mathrm{N}} \mathrm{Het}$ processes). ${ }^{4 e, 5}$ In the case of 6 chloro-2-iodo-9-isopropylpurine, Piguel and Legraverend showed that the Pd-catalysed reaction takes place at the $\mathrm{C} 2$ position with 
Table 1

$\mathrm{Pd}^{0}$-catalysed reactions of 2,6-dihalopurine nucleosides with benzamide, at different temperatures ${ }^{\mathrm{a}}$

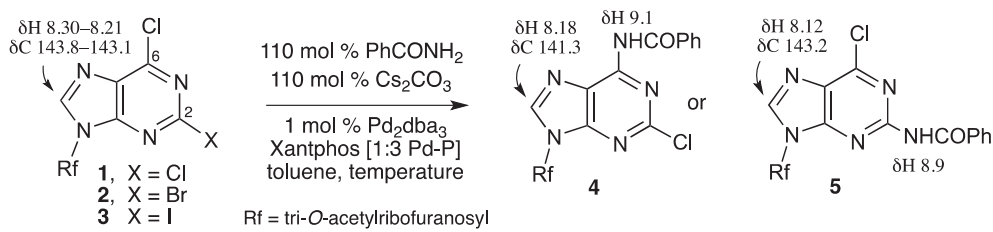

\begin{tabular}{llllll}
\hline Entry & Compound & $T\left({ }^{\circ} \mathrm{C}\right)$ & Time & Conv. $(\%)$ & Product, yield $^{\mathrm{b}}(\%)$ \\
\hline 1 & $\mathbf{1}$ & 20 & $48 \mathrm{~h}$ & 0 & - \\
2 & $\mathbf{1}$ & 50 & $6 \mathrm{~h}$ & 15 & $\mathbf{4}, 10$ \\
3 & $\mathbf{1}$ & 80 & $6 \mathrm{~h}$ & 100 & $\mathbf{4}, 87$ \\
4 & $\mathbf{2}$ & 20 & $48 \mathrm{~h}$ & 40 & $\mathbf{5}, 86$ \\
5 & $\mathbf{2}$ & 50 & $3 \mathrm{~h}$ & 100 & $\mathbf{5}, 80^{\mathrm{c}}$ \\
6 & $\mathbf{3}$ & 20 & $1 \mathrm{~h}$ & 100 & $\mathbf{5}, 88$ \\
7 & $\mathbf{3}$ & 50 & $24 \mathrm{~h}$ & 100 & $\mathbf{5}, 87$ \\
8 & $\mathbf{3}$ & 80 & $40 \mathrm{~h}$ & 100 & $\mathbf{5}, 82^{\mathrm{c}}$ \\
\hline
\end{tabular}

${ }^{a}$ Reaction conditions: $0.1 \mathrm{M}$ in anhyd. toluene, under $\mathrm{Ar}, 1.0 \mathrm{~mol} \%$ of $\mathrm{Pd}_{2} \mathrm{dba}_{3} \cdot \mathrm{CHCl}_{3}$ (that is, 0.02 equiv of $\mathrm{Pd}^{0}$ ), $3.0 \mathrm{~mol} \%$ of $\mathrm{Xant}-$ phos. Some experiments repeated with $\mathrm{Pd}_{2} \mathrm{dba}_{3}$ and $\mathrm{Pd}(\mathrm{dba})_{2}(2 \mathrm{~mol} \%$ in this last case $)$ did not show significant differences. ${ }^{12}$

${ }^{b}$ Isolated yields after flash column chromatography.

c The dibenzamido derivative was detected (5-10\%). See the main text.

full regioselectivity, ${ }^{6}$ that is, the preference of $\mathrm{Pd}^{0}$ to insert into the $\mathrm{C} 2-\mathrm{I}$ bond overcomes the higher intrinsic reactivity of position 6 in $\mathrm{S}_{\mathrm{N}} \mathrm{Het}$ reactions. In this connection, 2-bromo-6-chloro derivative $\mathbf{2}$ is a more challenging case, that is, a very appropriate substrate for the evaluation of the relative significance of both effects.

Thus, we treated $\mathbf{1 - 3 ^ { 7 }}$ with benzamide as a representative nitrogen source, in the presence of $1 \mathrm{~mol} \%$ of $\mathrm{Pd}_{2} \mathrm{dba}_{3} \cdot \mathrm{CHCl}_{3}(\mathrm{dba}=$ dibenzylideneacetone $=1,5$-diphenyl-1,4-pentadien-3-one) and $3 \mathrm{~mol} \%$ of Xantphos [4,5-bis(diphenylphosphino)-9,9-dimethylxanthene], ${ }^{8}$ at different temperatures, as shown in Table 1 . Although we had the feeling that the amount of catalyst could be even lower, we were more interested in avoiding long reaction times (owing to the possible decomposition of the nucleosidic substrates, as mentioned).

With 2,6-dichloro derivative $\mathbf{1}$, a temperature of $80^{\circ} \mathrm{C}$ was required for its total conversion to $\mathbf{4}$ (Table 1, compare entries $1-3) .{ }^{9}$ Substitution only took place on C6 (the product of substitution at $\mathrm{C} 2$, see $\mathbf{5}$, was not detected, under these conditions).

With 2 and 3, the replacements of $\mathrm{Br}$ and I at C2, respectively, were complete at $50{ }^{\circ} \mathrm{C}$ (Table 1 , entries 5 and 8 ) to give $5 .^{10}$ The mass spectra of the products, showing in one case the replacement of $2-\mathrm{Br}$ (but not that of 6-Cl) and in the other one the replacement of 2-I (but not that of 6-Cl), were conclusive. The reactivity differences between 2 and 3 were, however, significant at $20^{\circ} \mathrm{C}$ (compare entries 4 to 7 ). To summarize, the reactivity order appeared to be $2-\mathrm{I}>2-\mathrm{Br}>6-\mathrm{Cl} \gg 2-\mathrm{Cl}$. The order $2-\mathrm{I}>2-\mathrm{Br}>2-\mathrm{Cl}$ was expected, but the 'position' of $6-\mathrm{Cl}$ in this scale was unknown.

The case of $\mathbf{2}$ (2-Br vs 6-Cl) was the more interesting one. Below $80^{\circ} \mathrm{C}$ we only observed the replacement of $2-\mathrm{Br}(\mathbf{5}$, entry 5). At $80^{\circ} \mathrm{C}$, we detected a minor disubstitution product (footnote to entry 6 of Table 1 , see 6 below). Regarding the amount of base, the same outcome was obtained with $60 \mathrm{~mol} \%$ as with $110 \mathrm{~mol} \%$ of $\mathrm{Cs}_{2} \mathrm{CO}_{3}$; therefore, in these heterocyclic systems an excess of base is not crucial (saving of base is possible). Moreover, without $\mathrm{Pd} /$ Xantphos but with an excess of $\mathrm{Cs}_{2} \mathrm{CO}_{3}$, the reactions were very slow since, after $24 \mathrm{~h}$ at $80^{\circ} \mathrm{C}$ in toluene, $<10 \%$ of substitution at C6 took place. Even at $100{ }^{\circ} \mathrm{C}$ for $24 \mathrm{~h}$ with 2 equiv $\mathrm{PhCONH}_{2}$ and $200 \mathrm{~mol} \%$ of $\mathrm{Cs}_{2} \mathrm{CO}_{3}$, in the presence of Xantphos (but without Pd, of course), the substitution percentages were low (around $10 \%)$. Thus, the disubstitution byproduct-the observation of substitution at $\mathrm{C} 6$ in the experiments at $80^{\circ} \mathrm{C}$ for $\leqslant 1 \mathrm{~h}$, indicated in

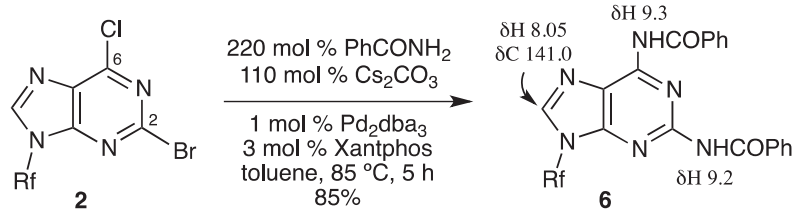

Scheme 1. Pd $^{0}$-catalysed double substitution of $\mathbf{2}$ with benzamide.

entries 6 and 9 of Table 1 -does not come from a $S_{N} A r$-like mechanism.

We then repeated the reaction of $\mathbf{2}$ with twice the amount of $\mathrm{PhCONH}_{2}$, at $85{ }^{\circ} \mathrm{C}$, with only $1 \mathrm{~mol} \%$ of $\mathrm{Pd}_{2} \mathrm{dba}_{3} \cdot \mathrm{CHCl}_{3}, 3 \mathrm{~mol} \%$ of Xantphos and $110 \mathrm{~mol} \%$ of $\mathrm{Cs}_{2} \mathrm{CO}_{3}$, as indicated in Scheme 1. Compound 2 was fully converted into 2,6-dibenzamido derivative 6. ${ }^{11}$ The isolated yield was $85 \%$.

Therefore, it appears that the $\mathrm{Pd}^{0}$ insertion occurs selectively at the more reactive $\mathrm{C} 2-\mathrm{Br}$ bond, but once this bromine atom has been replaced to a large extent, the insertion of $\mathrm{Pd}^{0}$ into the $\mathrm{C} 6-\mathrm{Cl}$ bond becomes competitive when the reaction temperature is $\geqslant 80^{\circ} \mathrm{C}$.

As the reaction of $\mathbf{3}$ had been complete at rt (Table 1, entry 7), we examined such a reaction at $0^{\circ} \mathrm{C}$. In toluene, the formation of the active Pd-Xantphos species ${ }^{13}$ (that is, the dba-to-Xantphos exchange) was not observed and benzamide was quite insoluble, so that the reaction did not go forward. However, it was sufficient to warm $\mathrm{Pd}_{2} \mathrm{dba}_{3}$ and Xantphos in toluene (at $60^{\circ} \mathrm{C}$ for a few seconds) and, after cooling to $0{ }^{\circ} \mathrm{C}$, to add a solution of $\mathbf{3}$ and benzamide in a similar volume of 1,4-dioxane to note a smooth progress of the cross-coupling reaction, as shown in entry 1 of Table 2 , with no secondary reactions (no deacetylation byproducts were observed at all). To the best of our knowledge (exhaustive SciFinder search), there are no precedents of efficient Pd-catalysed amidations carried out below room temperature. ${ }^{14}$ The replacement of the iodine atom of $\mathbf{3}$ was selective under these conditions as the bromo derivative, $\mathbf{2}$, did not react at all.

Could other similarly activated iodine atoms be selectively replaced below rt? We examined the Pd-catalysed reaction of $\mathrm{PhCONH}_{2}$ with two additional substrates ( 7 and 8, Table 2). ${ }^{15}$ Good 
Table 2

$\mathrm{Pd}^{0}$-catalysed reactions of iodo derivatives $3, \mathbf{7}$ and $\mathbf{8}$ with benzamide at $0{ }^{\circ} \mathrm{C}^{\mathrm{a}}$<smiles>[X]c1nc(Cl)c2ncn([R])c2n1</smiles>

3, $X=I$ 5, $X=1$
$X=$ NHCOPh<smiles>[X]c1nc(OCc2ccccc2)c2ncn([R])c2n1</smiles>

7, $X=I$
9, $X=$ NHCOPh<smiles>[X]c1nc(Cl)c2ncn(Cc3ccc(F)cc3)c2n1</smiles>

8, $X=I$

10, $X=$ NHCOPh

\begin{tabular}{llllll}
\hline Entry & Iodo deriv., concn. & $\mathrm{Pd}_{2} \mathrm{dba}_{3}, \mathrm{~mol} \%$ & Time & Conv. (\%) & Product, yield (\%) \\
\hline 1 & $\mathbf{3}, 0.1 \mathrm{M}$ & 1 & $48 \mathrm{~h}$ & 100 & $\mathbf{5}, 93$ \\
2 & $\mathbf{3}, 0.2 \mathrm{M}$ & 1 & $24 \mathrm{~h}$ & 100 & $\mathbf{5}, 96$ \\
3 & $\mathbf{7}, 0.2 \mathrm{M}$ & 1 & $36 \mathrm{~h}$ & 100 & $\mathbf{9}, 95$ \\
4 & $\mathbf{8}, 0.1 \mathrm{M}$ & 2.5 & $48 \mathrm{~h}^{\mathrm{b}}$ & 100 & $\mathbf{1 0}, 94^{\mathrm{b}}$ \\
5 & $\mathbf{8}, 0.2 \mathrm{M}$ & 2.5 & $28 \mathrm{~h}$ & 100 & $\mathbf{1 0}, 95$ \\
\hline
\end{tabular}

${ }^{a} \mathrm{Pd}_{2} \mathrm{dba}_{3} \cdot \mathrm{CHCl}_{3}(0.040 \mathrm{mmol})$ and Xantphos $(0.120 \mathrm{mmol})$ in anhyd. toluene $(10 \mathrm{~mL})$ were warmed under Ar. As soon as the wine-red suspension became greenish yellow (formation of the Pd-Xantphos complex), ${ }^{13}$ the flask was cooled to $0{ }^{\circ} \mathrm{C}$ (stock solution stored under Ar). For entries 2,3 and 5 , an aliquot $\left(2.5 \mathrm{~mL}\right.$ ) was added via syringe to a vial (bath at $0{ }^{\circ} \mathrm{C}$ ) with anhyd. $\mathrm{Cs}_{2} \mathrm{CO}_{3}(1.1 \mathrm{mmol})$. Afterwards, the iodo derivative $(1.0 \mathrm{mmol})$ and benzamide $(1.2 \mathrm{mmol})$ in 1,4-dioxane $(2.5 \mathrm{~mL})$, where benzamide is soluble, was added via syringe, and stirring was maintained at $0{ }^{\circ} \mathrm{C}$ for the time indicated, always under Ar.

b This experiment was repeated using a 1:2.1 Pd/P ratio instead of the standard 1:3 ratio, with a practically identical efficiency (conversion/ time).

Table 3

$\mathrm{Pd}^{0}$-catalysed reactions of $\mathbf{1}$ and $\mathbf{2}$ with amides, carbamates or nosylamides at $80^{\circ} \mathrm{C}$ for $6 \mathrm{~h}$, with the reagent ratios of Table 1

Entry Compd. Nucleoph.
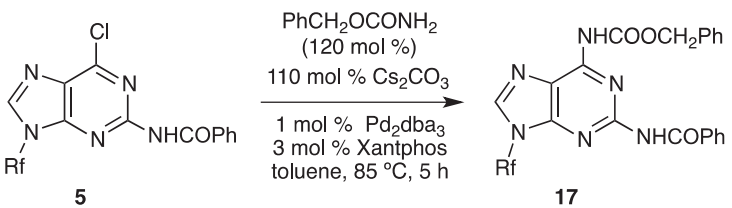

Scheme 2. Preparation of a $N^{2}, N^{6}$-disubstituted 2,6-diaminopurine.

conversions were observed, although the reactions were slightly slower than in the case of $\mathbf{3}$. To shorten the reaction times, we enhanced the substrate concentration to $0.2 \mathrm{M}$ (see entries 2,3 and 5) and/or that of the catalyst (entries 4 and 5); of course, there is room for improvement by operating at higher concentrations and with a large excess of $\mathrm{PhCONH}_{2}$, but we did not examine it. On the other hand, as it could be expected, iodobenzene did not react at all under these so mild conditions. In other words, only the most reactive $\mathrm{C}-\mathrm{I}$ bonds undergo the insertion of the $\mathrm{Pd}^{0} /$ Xantphos complex below rt.

Finally, to evaluate the scope of the reaction, other $\mathrm{N}$-nucleophiles were subjected to the standard conditions (Table 3 ). We chose $\mathbf{1}$ and $\mathbf{2}$ (instead of 3) as substrates because they are more challenging instances, never reported before, where the substitutions at $\mathrm{C} 2$ and C6 can compete. Isobutyramide, $\mathrm{O}$-benzyl carbamate, ${ }^{16}$ and $\mathrm{N}-2$ nitrobenzenesulfonylglycine methyl ester (o-nosyl- $\mathrm{NHCH}_{2} \mathrm{COOMe}$, $\mathrm{Ns}-\mathrm{Gly}-\mathrm{OMe}$ ) were chosen as nucleophile models. Although there are precedents of Pd-catalysed $\mathrm{N}$-arylations of sulfonamides, ${ }^{17}$ we have not found examples with the less reactive 0 -nosylamides; ${ }^{18}$ the Ns protecting group is more readily removed than standard sulfonyl groups. ${ }^{19}$ Reactions ran parallel to those of benzamide and isobutyramide, although they were slower. ${ }^{20}$

Replacement of halo substituents by two different amides, carbamates or sulfonamides seemed possible and could be an entry to diverse conjugates of 2,6-diamino-purines. As an example or 'proof of concept' we treated $\mathbf{5}$ with benzyl carbamate and $\mathrm{Cs}_{2} \mathrm{CO}_{3}$ in the presence of $\mathrm{Pd}^{\mathrm{O}} /$ Xantphos (Scheme 2), in toluene at $85^{\circ} \mathrm{C}$ for $5 \mathrm{~h}$, which gave disubstituted product 17. The conversion was complete but a partial decomposition of the carbamate group was noted (the isolated yield was around $60 \%)^{21}$ 
Only the activation of the 2-Cl substituent of $\mathbf{1}$ (and of 11-13) remained a challenge. We had attempted this replacement by forcing the reaction conditions in refluxing 1,4-dioxane but the crude contained many decomposition products. However, the conversion of $\mathbf{1}$ into the dibenzamido derivative, $\mathbf{6}$, could be achieved in toluene at $108-110{ }^{\circ} \mathrm{C}$ (bath temperature), in $90 \%$ isolated yield, within $6 \mathrm{~h}$, with $2.5 \mathrm{~mol} \%$ of $\mathrm{Pd}_{2}(\mathrm{dba})_{3}, 7.5 \mathrm{~mol} \%$ of Xantphos and $110 \mathrm{~mol} \%$ of $\mathrm{Cs}_{2} \mathrm{CO}_{3}$.

In summary, $\mathrm{Pd}^{0}$ and Xantphos are very suitable partners for the coupling of halopurine nucleosides with amides (either carboxamides, carbamates or nosylamides). The regioselectivity-reactivity order is $2-\mathrm{I}>2-\mathrm{Br}>6-\mathrm{Cl} \gg 2-\mathrm{Cl}$ (the $2-\mathrm{I}>2-\mathrm{Br}>2-\mathrm{Cl}$ order was expected, but the point was to establish the 'position' of $6-\mathrm{Cl}$ ). We have achieved the replacement of the iodine atom of 6-iodo-2chloro derivative 3 (and other similar iodo derivatives) at $0{ }^{\circ} \mathrm{C}$, a temperature at which the bromine of $\mathbf{2}$ is not substituted at all. Such a reactivity order permits to manipulate 2,6-dihalopurines in a proper way to attach protected amine groups either at $\mathrm{C} 2$ or C6. Via Pd-catalysed processes, it is also feasible to prepare differently $N^{2}, N^{6}$-disubstituted diaminopurines (potential nucleoside conjugates). Finally, even the more reluctant $2-\mathrm{Cl}$ substituent can be replaced by a benzamido group, in toluene at $110^{\circ} \mathrm{C}$, with a minimum amount of $\mathrm{Cs}_{2} \mathrm{CO}_{3}$ and reaction times as short as possible to avoid byproducts coming from the decomposition or saponification of sensitive substrates (protected purine nucleosides).

\section{Acknowledgments}

L.B. thanks TRIoH (EU, contract LHSB-CT2003 503480) and Fundació Privada Cellex of Barcelona (June 2009-June 2010) for stipends; he is currently a postdoc at CSIC (Barcelona). I.C. was a student funded by TRIoH and currently via Fundació Bosch Gimpera. J.C. thanks TRIoH (2007) and Fundació Cellex (June 2009-June 2010) for a fellowship; he is currently a postdoc of the Nagoya University. M.T. had a studentship from TRIoH and was later "Ajudant LOU" in our Department; she is currently a postdoc at the IRBB of Barcelona.

\section{References and notes}

1. For recent reviews, see: (a) Maiti, D.; Fors, B. P.; Henderson, J. L.; Nakamura, Y.; Buchwald, S. L. Chem. Sci. 2011, 2, 57-68; (b) Sadig, J. E. R.; Willis, M. C. Synthesis 2011, 1-22 (synthesis of heterocycles); (c) Surry, D. S.; Buchwald, S. L. Angew. Chem., Int. Ed 2008, 47, 6338-6361; (d) Hartwig, J. F. Acc. Chem. Res. 2008, 41, 1534-1544; (e) Fairlamb, I. J. S. Chem. Soc. Rev. 2007, 36, 1036-1045; (f) Buchwald, S. L. Mauger, C.; Mignani, G.; Scholz, U. Adv. Synth. Catal. 2006, 348, 23-39; (g) Schröter, S.; Stock, C.; Bach, T. Tetrahedron 2005, 61, $2245-$ 2267; (h) Lakshman, M. K. Curr. Org. Synth. 2005, 2, 83-112; for very recent references on the Pd-catalysed amidations or aminations, see: (i) Vimolratana, M.; Simard, J. L.; Brown, S. P. Tetrahedron Lett. 2011, 52, 1020-1022 (bidentate phosphines, 2-chloropyrimidine); (j) Thomson, P. F.; Lagisetty, P.; Balzarini, J. De Clercq, E.; Lakshman, M. K. Adv. Synth. Catal. 2010, 352, 1728-1735 (Xantphos as the best ligand)

2. For a very recent review on purvalanol $A$, a cyclin-dependent kinase inhibitor, see: (a) Tanowitz, H. B.; Machado, F. S. Cancer Biol. Ther. 2010, 10, 326-328; for reviews on nelarabine (drug approved against T-cell acute lymphoblastic leukemia), see: (b) Roecker, A. M.; Stockert, A.; Kisor, D. F. Clin. Med. Insights: Oncol 2010 4, 133-141; (c) Robak, T. Korycka, A ; Lech-Maranda, E.; Robak, P. Molecules 2009, 14, 1183-1226; for entries to purine nucleosides and analogues with cytotoxic or cytostatic activity, see: (d) Ottria, R.; Casati, S.; Manzocchi, A.; Baldoli, E.; Mariotti, M.; Maier, J. A. M.; Ciuffreda, P. Bioorg. Med. Chem. 2010, 18, 4249-4254; (e) Naus, P.; Pohl, R.; Votruba, I.; Dzubak, P.; Hajduch, M.; Ameral, R.; Birkus, G.; Wang, T.; Ray, A. S.; Mackman, R.; Cihlar, T.; Hocek, M. J. Med. Chem. 2010, 53, 460-470; also see the following review: (f) Legraverend, M.; Grierson, D. S. Bioorg. Med. Chem. 2006, 14, 3987-4006.

3. For an entry to the subject, see the following reviews: (a) Elzein, E.; Zablocki, J. Expert Opin. Investig. Drugs 2008, 17, 1901-1910; (b) Tosh, D. K.; Jacobson, K. A.; Jeong, L. S. Drugs Future 2009, 34, 43-52.

4. (a) Ariza, X.; Bou, V.; Vilarrasa, J. J. Am. Chem. Soc. 1995, 117, 3665-3673; (b) Terrazas, M.; Ariza, X.; Farràs, J.; Guisado-Yang, J. M.; Vilarrasa, J. J. Org. Chem. 2004, 69, 5473-5475; (c) Terrazas, M.; Ariza, X.; Vilarrasa, J. Tetrahedron Lett. 2005, 46, 5127-5130; (d) Terrazas, M.; Ariza, X.; Vilarrasa, J. Org. Lett. 2005, 7, 2477-2479; (e) Caner, J.; Vilarrasa, J. J. Org. Chem. 2010, 75, 4880-4883.
5. There are exceptions, however, depending on the nucleophile and medium. For an update, see: (a) Liu, J.; Robins, M. J. J. Am. Chem. Soc. 2007, 129, 5962-5968, and references cited therein; (b) we have confirmed in our lab that, with a commercially available solution of $\mathrm{NH}_{3}$ in 1,4-dioxane $(0.5 \mathrm{M})$, it was easy to introduce an amino group at $\mathrm{C} 6$, either at $50^{\circ} \mathrm{C}$ (overnight) or $80^{\circ} \mathrm{C}$ (for $2 \mathrm{~h}$ ) from 1-3 in a closed vial, without affecting at all bromine and iodine atoms at $\mathrm{C} 2$, that is, the reactions were very clean and, in spite of using 5 equiv of $\mathrm{NH}_{3}$, no substitution at $\mathrm{C} 2$ was observed; the chlorine atom of 6-chloro-2-cyano and 6-chloro-2-(benzylamino)carbonyl derivatives had been replaced by us under identical conditions (see: Bosch, L.; Vilarrasa, J. Tetrahedron Lett. 2011, 52, 753756); (c) in our hands, ammonia in anhydrous dioxane does not cleave the ester groups of the monosaccharide ring (see Robins, M. J.; Uznanski, B. Can. J. Chem. 1981, 59, 2608-2611, for related observations in DME); the aminodechlorination reactions were almost quantitative.

6. (a) Piguel, S.; Legraverend, M. J. Org. Chem. 2007, 72, 7026-7029; also see: (b) Vandromme, L.; Legraverend, M.; Kreimerman, S.; Lozach, O; Meijer, L.; Grierson, D. S. Bioorg. Med. Chem. 2007, 15, 130-141; (c) Li, X.; Vince, R. Bioorg. Med. Chem 2006, 14, 5742-5755; (d) Ibrahim, N.; Legraverend, M. J. Comb. Chem 2009, 11, 658-666; for other Pd-catalysed aminations and amidations of purines and purine nucleosides see Ref. 1.

7. Dichloro derivative $\mathbf{1}$ was prepared according to Refs. ${ }^{4 e, 5}$ as well as from the 2 amino-6-chloropurine nucleoside by diazotisation and halo-dediazoniation (tert-butyl nitrite or isopentyl nitrite, $\mathrm{Me}_{3} \mathrm{SiCl}, \mathrm{CH}_{2} \mathrm{Cl}_{2}$ ); see: (a) Francom, P.; Robins, M. J. J. Org. Chem. 2003, 68, 666-669; 2-bromo-6-chloro derivative 2 was also obtained by the last procedure (with $\mathrm{Me}_{3} \mathrm{SiBr}$ and $\mathrm{CH}_{2} \mathrm{Br}_{2}$ instead). We prepared 6-chloro-2-iodo derivative $\mathbf{3}$ by a related procedure, viz., by treatment of the amine with isopentyl nitrite, $\mathrm{I}_{2}, \mathrm{CH}_{2} \mathrm{I}_{2}$ and CuI in THF; see: (b) Matsuda, A. Shinozaki, M.: Yamaguchi, T.; Homma, H.; Nomoto, R.; Miyasaka, T.; Watanabe, Y.; Abiru, T. J. Med. Chem. 1992, 35, 241-252; (c) Nair, V.; Richardson, S. G. Synthesis 1982, 670-672.

8. For a review, see: Birkholz, M.-N.; Freixa, Z.; van Leeuwen, P. W. N. M. Chem. Soc. Rev. 2009, 38, 1099-1118.

9. 6-Benzamido-2-chloro-9-(2', $3^{\prime}, 5^{\prime}$-tri-O-acetyl- $\beta$-D-ribofuranosyl)-purine (4): white foam; ${ }^{1} \mathrm{H}$ NMR $\left(\mathrm{CDCl}_{3}, 400 \mathrm{MHz}\right) \delta 2.07(\mathrm{~s}, 3 \mathrm{H}), 2.12(\mathrm{~s}, 3 \mathrm{H}), 2.15(\mathrm{~s}$, $3 \mathrm{H}), 4.39(\mathrm{~d}, J=3.6 \mathrm{~Hz}, 2 \mathrm{H}), 4.45(\mathrm{~m}, 1 \mathrm{H}), 5.58(\mathrm{dd}, J=4.1,5.5,1 \mathrm{H}), 5.80(\mathrm{t}$, $J=5.7,1 \mathrm{H}), 6.24(\mathrm{~d}, J=5.9,1 \mathrm{H}), 7.49(\mathrm{t}, J=7.7,2 \mathrm{H}), 7.59(\mathrm{t}, J=7.4,1 \mathrm{H}), 8.00(\mathrm{~d}$, $J=7.3,2 \mathrm{H}), 8.18(\mathrm{~s}, 1 \mathrm{H}), 9.09$ (br s, $1 \mathrm{H}) ;{ }^{13} \mathrm{C}$ NMR $\left(\mathrm{CDCl}_{3}, 100.6 \mathrm{MHz}\right) \delta 20.3$ $\left(\mathrm{CH}_{3}\right), 20.5\left(\mathrm{CH}_{3}\right), 20.7\left(\mathrm{CH}_{3}\right), 63.0\left(\mathrm{CH}_{2}\right), 70.6(\mathrm{CH}), 73.1(\mathrm{CH}), 80.6(\mathrm{CH}), 85.8$ $(\mathrm{CH}), 122.8(\mathrm{C}), 128.0(\mathrm{CH}), 128.8(\mathrm{CH}), 132.6(\mathrm{C}), 133.1(\mathrm{CH}), 141.3(\mathrm{CH}), 150.6$ (C), $153.6(\mathrm{C}), 153.8(\mathrm{C}), 164.4$ (C), 169.3 (C), 169.5 (C), 170.2 (C); HRMS (ESI) $\mathrm{m} /$ $z$ calcd for $\left[\mathrm{C}_{23} \mathrm{H}_{23}{ }^{35} \mathrm{ClN}_{5} \mathrm{O}_{8}\right]^{+}\left(\mathrm{M}+\mathrm{H}^{+}\right) \quad 532.1235$ and $\left[\mathrm{C}_{23} \mathrm{H}_{22}{ }^{35} \mathrm{ClN}_{5} \mathrm{NaO}_{8}\right]^{+}$ $\left(\mathrm{M}+\mathrm{Na}^{+}\right) 554.1055$, found 532.1228 and 554.1046

10. 2-Benzamido-6-chloro-9-( $2^{\prime}, 3^{\prime}, 5^{\prime}$-tri- $O$-acetyl- $\beta$-D-ribofuranosyl)purine (5): white solid foam; mp $70-71{ }^{\circ} \mathrm{C} ;{ }^{1} \mathrm{H}$ NMR $\left(\mathrm{CDCl}_{3}, 400 \mathrm{MHz}\right) \delta 2.07(\mathrm{~s}, 3 \mathrm{H})$, $2.11(\mathrm{~s}, 3 \mathrm{H}), 2.17(\mathrm{~s}, 3 \mathrm{H}), 4.53(\mathrm{~m}, 3 \mathrm{H}), 5.95(\mathrm{~m}, 2 \mathrm{H}), 6.16(\mathrm{~d}, J=3.9,1 \mathrm{H}), 7.50(\mathrm{t}$, $J=7.5,2 \mathrm{H}), 7.58(\mathrm{t}, J=7.4,1 \mathrm{H}), 7.96(\mathrm{~d}, J=7.2,2 \mathrm{H}), 8.14(\mathrm{~s}, 1 \mathrm{H}), 8.91(\mathrm{br} \mathrm{s}, 1 \mathrm{H})$; ${ }^{13} \mathrm{C}$ NMR $\left(\mathrm{CDCl}_{3}, 100.6 \mathrm{MHz}\right) \delta 20.4\left(\mathrm{CH}_{3}\right), 20.5\left(\mathrm{CH}_{3}\right), 20.7\left(\mathrm{CH}_{3}\right), 63.5\left(\mathrm{CH}_{2}\right)$, $70.8(\mathrm{CH}), 73.6(\mathrm{CH}), 80.6(\mathrm{CH}), 87.5(\mathrm{CH}), 127.5(\mathrm{CH}), 128.8(\mathrm{CH}), 129.0(\mathrm{C})$, $132.5(\mathrm{CH}), 133.9(\mathrm{C}), 143.2(\mathrm{CH}), 151.6(\mathrm{C}), 152.0(\mathrm{C}), 152.2(\mathrm{C}), 164.1(\mathrm{C})$, 169.5 (C), 169.5 (C), 169.6 (C); HRMS (ESI) $\mathrm{m} / z$ calcd for $\left[\mathrm{C}_{23} \mathrm{H}_{23}{ }^{35} \mathrm{ClN}_{5} \mathrm{O}_{8}\right]^{+}$ $\left(\mathrm{M}+\mathrm{H}^{+}\right) 532.1235$ and $\left[\mathrm{C}_{23} \mathrm{H}_{22}{ }^{35} \mathrm{ClN}_{5} \mathrm{NaO}_{8}\right]^{+}\left(\mathrm{M}+\mathrm{Na}^{+}\right)$554.1055, found 532.1239 and 554.1060 .

11. 2,6-Dibenzamido-9-(2',3',5'-tri-O-acetyl- $\beta$-D-ribofuranosyl)purine $(\mathbf{6})$ : white solid foam; mp 109-110 ${ }^{\circ} \mathrm{C} ;{ }^{1} \mathrm{H} \mathrm{NMR}\left(\mathrm{CDCl}_{3}, 400 \mathrm{MHz}\right) \delta 2.06(\mathrm{~s}, 3 \mathrm{H}), 2.10(\mathrm{~s}$, $3 \mathrm{H}), 2.15(\mathrm{~s}, 3 \mathrm{H}), 4.50(\mathrm{~m}, 3 \mathrm{H}), 5.99(\mathrm{~m}, 2 \mathrm{H}), 6.16(\mathrm{~d}, J=2.5,1 \mathrm{H}), 7.48(\mathrm{~m}, 4 \mathrm{H})$, $7.54(\mathrm{~m}, 2 \mathrm{H}), 8.00(\mathrm{~m}, 4 \mathrm{H}), 8.05(\mathrm{~s}, 1 \mathrm{H}), 9.21(\mathrm{br} \mathrm{s}, 1 \mathrm{H}), 9.34(\mathrm{br} \mathrm{s}, 1 \mathrm{H}) ;{ }^{13} \mathrm{C} \mathrm{NMR}$ $\left(\mathrm{CDCl}_{3}, 100.6 \mathrm{MHz}\right) \delta 20.4\left(\mathrm{CH}_{3}\right), 20.5\left(\mathrm{CH}_{3}\right), 20.7\left(\mathrm{CH}_{3}\right), 63.4\left(\mathrm{CH}_{2}\right), 70.8(\mathrm{CH})$, $73.4(\mathrm{CH}), 80.3(\mathrm{CH}), 86.9(\mathrm{CH}), 120.7(\mathrm{C}), 127.6(\mathrm{CH}), 127.9(\mathrm{CH}), 128.6(\mathrm{CH})$, $128.7(\mathrm{CH}), 132.1(\mathrm{CH}), 132.7(\mathrm{CH}), 133.2(\mathrm{C}), 134.2(\mathrm{C}), 141.0(\mathrm{CH}), 150.1(\mathrm{C})$, 152.5 (C), 152.6 (C), 164.7 (C), 164.7 (C), 169.5 (C), 169.6 (C), 170.4 (C); HRMS (ESI) $\mathrm{m} / z$ calcd for $\left[\mathrm{C}_{30} \mathrm{H}_{29} \mathrm{~N}_{6} \mathrm{O}_{9}\right]^{+}\left(\mathrm{M}+\mathrm{H}^{+}\right) 617.1996$ and $\left[\mathrm{C}_{30} \mathrm{H}_{28} \mathrm{~N}_{6} \mathrm{NaO}_{9}\right]^{+}$, $\left(\mathrm{M}+\mathrm{Na}^{+}\right)$639.1815, found 617.1992 and 639.1822.

12. Palladium diacetate, provided that it was previously reduced to $\mathrm{Pd}^{0}$ by heating with a small amount of water and a biarylphosphine, was very recently recommended for the coupling of aryl chlorides with carboxamides or ureas. See: (a) Fors, B. P.; Krattiger, P.; Strieter, E.; Buchwald, S. L. Org. Lett. 2008, 10, 3505-3508; (b) Fors, B. P.; Dooleweert, K.; Zeng, Q.; Buchwald, S. L. Tetrahedron 2009, 65, 6576-6583; (c) Breitler, S.; Oldenhuis, N. J.; Fors, B. P.; Buchwald, S. L. Org. Lett 2011, 13, 3262-3265.

13. [Pd(dba)Xantphos] may be the predominant species according to studies on the nature of bidentate phosphine-Pd complexes: (a) Amatore, C.; Broeker, G.; Jutand, A.; Khalil, F. J. Am. Chem. Soc. 1997, 119, 5176-5185; (b) Klingensmith, L. M.; Strieter, E. R.; Barder, T. E.; Buchwald, S. L. Organometallics 2006, 25, 8291

14. There are several examples, however, of efficient Kumada-Corriu couplings (RMgX, ArX, Pd) even below $0^{\circ} \mathrm{C}$ : (a) Bonnet, V.; Mongin, F.; Trécourt, F.; Quéguiner, G. Knochel, P. Tetrahedron Lett. 2001, 42, 5717-5720; (b) Bonnet, V.; Mongin, F.; Trécourt, F.; Quéguiner, G.; Knochel, P. Tetrahedron 2002, 58, 4429-4438; (c) Organ, M. G.; Abdel-Hadi, M.; Avola, S.; Hadei, N.; Nasielski, J.; O'Brien, C. J.; Valente, C. Chem. Eur. J. 2007, 13, 150-157; (d) Martin, R.; Buchwald, S. L. J. Am. Chem. Soc. 2007, 129, 3844-3845; there is one example ( $\mathrm{ArCl}$, morpholine, LiHMDS, SPhos-Pd0, $-10^{\circ} \mathrm{C}$, DME) of amination below rt; (e) Biscoe, M. R.; Fors, B. P.; Buchwald, S. L. J. Am. Chem. Soc. 2008, 130, 66866687; for Negishi reactions below rt, see: (f) Liu, J.; Deng, Y.; Wang, H.; Zhang, H.; Yu, G.; Wu, B.; Zhang, H.; Li, Q.; Marder, T. B.; Yang, Z.; Lei, A. Org. Lett. 2008, 10, 2661-2664; (g) Wunderlich, S.; Knochel, P. Chem. Commun. 2008, 6387; (h) 
Liu, J.; Wang, H.; Zhang, H.; Wu, X.; Zhang, H.; Deng, Y.; Yang, Z.; Lei, A. Chem. Eur. J. 2009, 15, 4437-4445; (i) Thaler, T.; Haag, B.; Gavryushin, A.; Schober, K.; Hartmann, E.; Gschwind, R. M.; Zipse, H.; Mayer, P.; Knochel, P. Nature Chem. 2010, 2, 125-130; (j) Calimsiz, S.; Sayah, M.; Mallik, D.; Organ, M. G. Angew. Chem., Int. Ed. 2010, 49, 2014-2017; for a Suzuki coupling below rt, see: (k) Urbaneja, X.; Mercier, A.; Besnard, C.; Kündig, E. P. Chem. Commun. 2011, 47 3739-3741; for a Sonogashira reaction, see: (1) Nakamura, K.; Okubo, H.; Yamaguchi, M. Synlett 1999, 549-550.

15. We prepared $\mathbf{7}$ from $\mathbf{3}$ and benzyl alcohol and $\mathrm{NaH}$ at $\mathrm{rt}$, that is, via a SNAr-like reaction, while $\mathbf{8}$ was prepared according to the procedure of Gundersen et al. for the analogous benzyl derivative: Langli, G.; Gundersen, L.-L.; Rise, F. Tetrahedron 1996, 52, 5625-5638.

16. For illustrative papers on the use of carbamates, see: (a) Mullick, D.; Anjanappa, P.; Selvakumar, K.; Ruckmani, K.; Sivakumar, M. Tetrahedron Lett 2010, 51, 5984-5987 ( $\mathrm{Pd}^{\mathrm{II}}$, Xantphos, $\mathrm{TMSCH}_{2} \mathrm{CH}_{2} \mathrm{OCONH}{ }_{2}$ ), and references therein: (b) Oin, L. Cui, H. Zou, D. Li, J. Wu, Y. Zhu, Z:Wu, Y. Tetrahedron Lett. 2010, 51, 4445-4448 $\left(\right.$ BocNH $\left._{2}\right)$; (c) Mantel, M. L. H.; Lindhardt, A. T.; Lupp, D.; Skrydstrup, T. Chem. Eur. J. 2010, 16, 5437-5442 (tosylates, oxazolidin-2one); (d) Hicks, J. D.; Hyde, A. M.; Martínez-Cuezva, A.; Buchwald, S. L. J. Am. Chem. Soc. 2009, 131, 16720-16734 (N-subst. carbamates \& sulfonamides); (e) Bhagwanth, S.; Waterson, A. G.; Adjabeng, G. M.; Hornberger, K. R. J. Org. Chem. 2009, 74, 4634-4637 (BocNH ${ }_{2}{ }^{t} \mathrm{BuXPhos}$ preferred, rt): (f) Trabanco, A. A. Vega, J. A.; Fernández, M. A. J. Org. Chem. 2007, 72, 8146-8148 (fluorinated carbamates); (g) Audisio, D.; Messaoudi, S.; Peyrat, J.-F.; Brion, J.-D.; Alami, M. Tetrahedron Lett 2007, 48, 6928-6932 (Pd ${ }^{\mathrm{II}}$, Xantphos preferred, carbamates \& sulfonamides); (h) Fujita, K.; Yamashita, M.; Puschmann, F.; Alvarez-Falcon, M. M.; Incarvito, C. D.; Hartwig, J. F. J. Am. Chem. Soc 2006, 128, 9044-9045 (Xantphos, 2-oxazolidinone and TsNHMe)

17. (a) Yin, J.; Buchwald, S. L. Org. Lett 2000, 2, 1101-1104; (b) Yin, J.; Buchwald, S. L. J. Am. Chem. Soc 2002, 124, 6043-6048; (c) Burton, G.; Cao, P.; Li, G.; Rivero, R. Org. Lett 2003, 5, 4373-4376; (d) Steinhuebel, D.; Palucki, M.; Askin, D.; Dolling, U. Tetrahedron Lett. 2004, 45, 3305-3307 (sultams); (e) Carril, M.
SanMartín, R.; Domínguez, E.; Tellitu, I. Tetrahedron 2007, 63, 690-702; (f) Ikawa, T.; Barder, T. E.; Biscoe, M. R.; Buchwald, S. L. J. Am. Chem. Soc 2007, 129, 13001-13007; (g) Porter, J.; Lumb, S.; Lecomte, F.; Reuberson, J.; Foley, A. Calmiano, M.; le Riche, K.; Edwards, H.; Delgado, J.; Franklin, R. J.; GasconSimorte, J. M.; Maloney, A.; Meier, C.; Batchelor, M. Bioorg. Med. Chem. Lett. 2009, 19, 397-400; (h) Johns, B. A.; Weatherhead, J. G.; Allen, S. H.; Thompson, J. B.; Garvey, E. P.; Foster, S. A.; Jeffrey, J. L.; Miller, W. H. Bioorg. Med. Chem. Lett. 2009, 19, 1807-1810; (i) Micheli, F.; Bonanomi, G.; Di Fabio, R.; Gentile, G.; Tarsi, L.; Terreni, S.; Hamprecht, D.; Donati, D.; Heidbreder, C.; Prandi, A. Bioorg. Med. Chem. Lett. 2010, 20, 5491-5494; (j) Shetty, R. S.; Lee, Y.; Liu, B.; Husain, A.; Joseph, R. W.; Lu, Y.; Nelson, D.; Mihelcic, J.; Chao, W.; Moffett, K. K.; Schumacher, A.; Flubacher, D.; Stojanovic, A.; Bukhtiyarova, M.; Williams, K.; Lee, K.-J.; Ochman, A. R.; Saporito, M. S.; Moore, W. R.; Flynn, G. A.; Dorsey, B. D.; Springman, E. B.; Fujimoto, T.; Kelly, M. J. J. Med. Chem. 2011, 54, 179-200; (k) Liu, B.; Shetty, R. S.; Moffett, K. K.; Kelly, M. J. Tetrahedron Lett. 2011, 52, 1680-1684; (1) Rosen, B. R.; Ruble, J. C.; Beauchamp, T. J.; Navarro, A. Org. Lett. 2011, 13, 2564-2567; (m) Shekhar, S.; Dunn, T. B.; Kotecki, B. J.; Montavon, D. K.; Cullen, S. C. J. Org. Chem. 2011, 76, 4552-4563. Also see Refs. 16d and 16g. 18. Cul-promoted reactions are well known, however.

19. (a) Fukuyama, T.; Jow, C.-K.; Cheung, M. Tetrahedron Lett. 1995, 36, 6373-6374 (b) Hidai, Y.; Kan, T.; Fukuyama, T. Tetrahedron Lett. 1999, 40, 4711-4714; (c) Kan, T.; Fukuyama, T. Chem. Commun. 2004, 353-359; (d) Aihara, Y. Yoshida, A.; Furuta, T.; Wakimoto, T.; Akizawa, T.; Konishi, M.; Kan, T. Bioorg. Med. Chem. Lett. 2009, 19, 4171-4174. Also see Ref. 4c.

20. In preliminary experiments, Boc-Gly-OMe also reacted slowly.

21. A one-pot trial from $\mathbf{2}$, adding first the carboxamide and then the carbamate gave a similar outcome. For sequential replacements of two halogens via Suzuki reactions, with parallel results, see: (a) Čerňa, I.; Pohl, R.; Klepetářová, B.; Hocek, M. J. Org. Chem. 2008, 73, 9048-9054; (b) Čerňa, I.; Pohl, R.; Klepetářová, B.; Hocek, M. Org. Lett. 2006, 8, 5389-5392; (c) Havelková, M.; Dvořák, D.; Hocek, M. Synthesis 2001, 1704-1710. 